\title{
ZAGADNIENIE SENSOWNOŚCI PYTANIA O POCZĄTEK CZASOWY WSZECHŚWIATA
}

Sensowność pytania o początek czasowy kosmosu zdaje się aktualnie zaciemniać w następstwie nadawania przez niektórych autorów filozoficznego sensu doktrynalnego temu, co we współczesnej kosmologii przyrodniczej jest wyrazem infinityzmu lub rela-tywizmu metodologicznego, a także w następstwie wysuwanej czasem nieadekwatnej interpretacji relacyjnej kon cepcji czasu. Sugestie w kierunku ujęcia doktrynalnego, opartego na wskazanych podstawach, znajdujemy m. in. u Michała Hellera.

Niektóre jego wypowiedzi nie mogą budzić zastrzeżeń. I tak, zgodzimy się z nim, gdy pisze: „[...] zgodnie z filozofią stworzenia Stwórca móg! zrealizować świat według jakiegokolwiek modelu. Nie musiał koniecznie wybierać modeli »z początkiem«. Więcej nawet, nie musiał wypowiadać »stań się!« w momencie zwanym przez kosmologię chwilą zero. Był władny stworzyć świat w dowolnym etapie jego ewolucji. Nie jest to zabezpieczenie się na wszelką ewentualność: gdyby tak przypadkiem nauka opowiedziała się kiedyś za modelem bez początku i bez ewolucji. To prosta konsekwencja z przypisywania Stwórcy atrybutu wszechmocy" 1 .

Zgodzimy się również z twierdzeniem Hellera, że ,dla światopoglądu zasadniczym pytaniem nie jest to, czy świat miał początek, czy też jest wieczny, lecz pytanie: co jest pierwotne: materia czy duch?" 2. W tym zasadniczo sensie wypowiadał się już Antonin D. Sertillanges ${ }^{3}$. Trudno jednak nie mieć zastrzeżeń, gdy Heller sięga do kosmologii przyrodniczej, by przytoczyć dalsze argumenty na rzecz tezy, że ,kwestia początku nie

1 Wobec wszechświata, Kraków 1970, 166.

2 Pojęcie kreacjonizmu a wspólczesna kosmologia, ,Znak", 24 (1972) 329.

3 L'idée de création et ses retentissements en philosophie, Paris 1945, 7-8. 
jest aż tak istotna, jak się nam dawniej wydawało". Chodzi o następujące rozumowanie:

Pytania o „początek” pojawiają się jedynie w uproszczonych modelach kosmologicznych. Jedno $z$ wprowadzonych do nich uproszczeń polega na tym, że zakłada się, iż materia rozpościera się w przestrzeni jednostajnie, nie mając wyróżnionych kierunków i punktów. Po przyjęciu takiego założenia można mówić o jednym czasie uniwersalnym, o czasie kosmicznym, oraz o jego początku, który - według teorii ekspansji wszechświata - będzie miał miejsce $w$ super-gęstych stadiach jego ewolucji. Gdy nie wprowadzimy wskazanego założenia upraszczającego, nie wystąpi pojęcie czasu kosmicznego, o którego początek moglibyśmy się pytać. Następstwem tego będzie zrelatywizowanie sprawy początku czasowego czy wieczności kosmosu. Okazuje się, że „to, czy świat jest wieczny, czy nie, może zależeć od wyboru układu odniesienia: w pewnych układach odniesienia konkretny model świata może odznaczać się nieskończonym wiekiem, w innych układach odniesienia ten sam model może posiadać wiek skończony. Ponadto E. A. Milne pokazał, że wiek świata w istotny sposób zależy od rodzaju zegarów, przy pomocy których ten wiek mierzymy. Jeśli mamy model kosmologiczny, w którym występuje początkowa chwila osobliwa [z nieskończoną gęstością materii], to dobierając odpowiedni rodzaj zegarów (skalę czasu) daje się osiągnąc taki efekt, że początkowa osobliwość cofa się do minus nieskończoności, świat staje się wieczny. Tego rodzaju sytuacja ma miejsce w modelu kosmologicznym skonstruowanym przez samego Milne'a. W modelu tym wiek świata mierzony zegarem atomowym jest skończony (ewolucja świata miała początek), natomiast wiek świata mierzony zegarem grawitacyjnym jest nieskończony (świat jest wieczny)". Dodajmy jeszcze, że ponieważ w super-gęstych stadiach ewolucji kosmicznej cząstki tracą swą indywidualność, dlatego w odniesieniu do tych stadiów nie można stosować pojęcia czasu jako czegoś płynącego w określonym kierunku, gdyż to pojęcie zakłada wielość jednostek, czyli to, co nazywamy masą statystyczną. W dalszej konsekwencji staje się bezsensownym pytanie o początek czasu ${ }^{4}$.

Przytoczona argumentacja Hellera nie może nas przekonać, gdyż chodzi mu o dowód tezy, że „dziś pytanie o początek świata traci wagę światopoglądową, jaką miało kiedyś", a powołuje się na to, przy jakich założeniach i przy uwzględnieniu jakich układów odniesienia oraz zegarów pomiarowych będziemy mówili w kosmologii przyrodniczej o początku czasowym lub o wieczności obecnej ewolucji wszechświata. Racja, jaką przytacza Heller, nie ma więc nic wspólnego z tezą przez $\mathrm{ni}$ e g d owodzon ą. Jego argumentację obciąża ponadto okoliczność,

4 Art. cyt., 328-329; szkic zamieszczony w dziele Wincentego Granata $K u$ człowiekowi i Bogu w Chrystusie, t. I, Lublin 1972, 172. 
że z relatywizmu metodologicznego współczesnej kosmologii przyrodniczej, do którego się odwołuje, nie można wyprowadzić żadnych wniosków filozoficznych. Trzeba jeszcze zauważyć, że chociaż do super-gęstych stadiów ewolucji kosmicznej nie można, z powodów podanych wyżej, stosować pojęcia czasu jako czegoś upływającego kierunkowo, to jednak z tego nie wynika, żebyśmy, inspirując się arystotelesowsko-tomistyczną koncepcją czasu, nie mogli pytać się, czy przed tzw. osobliwością, punktem początkowym ekspansji kosmosu, nic może nie było. Heller utrzymuje, że takie założenie jest hipotezą ,nietwórczą" 5 . Otóż tak rzecz przedstawia się dla kos mologa - przy rodnika, który znajduje podnietę do dalszych badań przyjmując po linii metodologicznego infinityzmu nie początek istnienia wszechświata, lecz początek jego obecnej ewolucji. Natomiast dla filozof a przy rody, poruszającego się w innej niż kosmolog - przyrodnik płaszczyźnie neomatycznej, wskazane przypuszczenie będzie miało charakter twórczy, o ile pobudzi go do zbadania, czy ma ono jakiś sens i czy da się uzasadnić teza o początku czasowym istnienia wszechświata.

Dla Hellera pytanie o początek istnienia kosmosu staje się pytaniem bezprzedmiotowym nie tylko na gruncie modelu gorącego wszechświata tego modelu, który jest uważany za najbardziej zgodny z danymi doświadczenia. Wymienione pytanie traci również dla naszego autora swe uzasadnienie po przyjęciu relacyjnej teorii czasu ${ }^{6}$.

Według tej teorii ,czas stanowi pewną relację porządkującą zdarzenia w świecie materialnym", tak że bez tych zdarzeń nie ma sensu mówic o czasie ${ }^{7}$. Heller $w$ ten sposób argumentuje na rzecz swego twierdzenia, że ,z punktu widzenia relacyjnej teorii czasu właściwie trudno mówić o początku”: „Samo pojęcie początku zakłada, że przedtem czegoś (czego początek mam na myśli) nie było, nie było świata, był pusty czas. Skutkiem tego w relacyjnej teorii czasu prawdziwe jest twierdzenie, że świat istniał zawsze, nawet jeśli się przyjmie, że został stworzony przez Boga. Bo zawsze, od kiedy istniał czas, świat już był. Czas jest tylko relacja między materialnymi zdarzeniami; gdy nie ma zdarzeń, nie ma czasu" s.

Nie wchodzę w tej chwili w kwestię, czy Heller ma rację przenosząc bez reszty czas w obręb porządku obiektywnego, a więc pomijając całkowicie w jego przypadku jakikolwiek czynnik podmiotowy. Chciałbym natomiast zauważyć, że jego argumentacja, która zdaje się być do pew-

5 Art cyt., 327.

6 Zdaniem Hellera relacyjną teorię czasu mamy $\mathrm{m}$. in. $\mathrm{w}$ tomiźmie. Pojmowanie czasu w tym kierunku filozoficznym ma mieć jednak charakter nieco prymitywny, gdyż - według niego - „czas, jest to zliczanie pewnych "faz w ruchu«". Art. cyt., 323-324.

7 Tamże, 323.

¿ Tamże, 1. c. 
nego stopnia przekształceniem wywodów Sertillanges'a ${ }^{9}$, nie może nas przekonać. Polemizując z Hellerem będziemy również wypowiadali się z pozycji następstw logicznych arystotelesowsko-tomistycznej teorii czasu, która jest w jakimś sensie teorią relacyjną.

W sposób konsekwentny powinniśmy rozumować w ten sposób, że jeżeli czas jest swoistą relacją porządkującą zdarzenia materialne, to czas może mié́ początek lub może go nie posiadać. Wszystko zależ od tego, czy w dziejach wszechświata ilość dopełnionych par zdarzeń materialnych, stanowiących podstawędla relacjiczasowej a rozpatrywanych od jakiegoś, teraz", jest skończon a lub niesk oń c z ona. Jeżeliby ilość tych par zdarzeń była skończona, dzieje wszechświata miałyby jakieś zdarzenia materialne absolutnie pierwsze, a w następstwie tego miałyby również początek czasowy. Jeżeliby znów ilość wskazanych par zdarzeń była nieskończona, dzieje kosmosu nie posiadałyby żadnych zdarzeń absolutnie pierwszych, a tym samym żadnego początku w swym trwaniu czasowym.

Jeżeli przyjmie się, że czas bez zdarzeń jest fikcją, trzeba powiedzieć, że ,zawsze, od kiedy istniał czas, świat już był”. Ale to stwierdzenie jak wynika z przeprowadzonych dopiero co analiz - nie jest r ó w n oważne tezie o od wiecznym istnieniu świata. Możemy je stosować zarówno do świata z początkiem, jak i bez początku. A licząc się z możliwością początku świata, wcale nie rozstajemy się z relacyjną teorią czasu i nie utrzymujemy, że przed zaistnieniem świata był pusty czas. Taki czas może być tylko fikcją.

Okazuje się, że pytanie o ewentualny początek czasowy kosmosu, wysuwane z pozycji filozofii przyrody, nie straciło swego dawnego sensu ani przy uwzględnieniu materialnej (w znaczeniu metodologicznym) za-

9 Francuski dominikanin $\mathrm{w}$ tych słowach przedstawił swe stanowisko: „Nous sommes [...] obligés de dire, [...] qu'en toute hypothèse, même en supposant un début de la durée, comme c'est le cas ordinaire des chrétiens, que le monde a toujours existé. Mais oui, puisqu'il n'y a pas de jour où il n'était pas existé [...] Lorsqu'il s'agit d'un être particulier dans le temps, il y a contradiction à dire qu'il a commencé et qu'il a toujours existé, parce qu'il y a une durée antérieure pendant laquelle il n'existait pas. Mais pour l'ensemble du monde, il n'y a pas de contradiction, puisqu'il n'y a pas de temps en arrière et que le tout du monde comprend aussi le tout de la durée". Dz. cyt., 12. Por. jeszcze tamże s. 13-15 oraz w innej pracy tego autora Le christianisme et les philosophies, Paris 1946, t. I, 267.

$\mathrm{W}$ swych wywodach, rozwiniętych najszerzej $\mathrm{w}$ L'idée de création et ses retentissements en philosophie, Sertillanges nawiązywał w twórczy sposób m. in. do sformułowań Tomasza z Akwinu z De potentia Dei, qu. III, a. 18, ad 20: ,[...] Angeli dicuntur semper fuisse, non quia ab aeterno fuerunt, sed quia omni tempore fuerunt: quia quandocumque fuit tempus, fuerunt Angeli. Et per hunc etiam modum creaturae corporales semper fuerunt". Natomiast argumentacja Hellera nie jest dosłownym podjęciem tego rozumowania, gdyż - według niego - teza, że kosmos istniał zawsze, nie daje się pogodzić z tezą o jego początku czasowym. Heller najwyraźniej zmienił sens wywodów Sertillanges'a, jeżeli z nich korzystał. 
leżności od współczesnej kosmologii przyrodniczej, ani przy opowiedzeniu się za relacyjną teorią czasu. Wymienione pytanie moglibyśmy nazwać za Piotrem Teilhardem de Chardin ${ }^{10}$ pytaniem o początek ontolog i c z n y (un commencement ontologique) wszechświata. Sciślej jednak określilibyśmy je jako pytanie o ontologiczny początek czasowy kosmosu.

Jest ono takim pytaniem z kilku powodów. Najpierw dlatego, że dotyczy początku czasowego istnienia wszechświata, które to istnienie rozpatrujemy nie w relacji do strony zjawiskowej rzeczy materialnych, lecz w odniesieniu do przysługującego im typu bytu oraz właściwej im struktury bytowej, a przy tym, włączając do tak rozumianego istnienia czas jako jego charakterystyczny modus, bierzemy go według filozoficznej teorii Arystotelesa i Tomasza z Akwinu, a nie w ujęciu empirio-metrycznym kosmologa - przyrodnika ${ }^{11}$. Wymienione pytanie jest także pytaniem o ontologiczny początek czasowy wszechświata z tej racji, że wysuwa się je w ramach poznania z dziedziny filozofii przyrody, które możemy nazwać poznaniem ontologicznym w znaczeniu szerszym, gdyż jest ześrodkowane nie na bycie jako takim, ale na tym bycie spartykularyzowanym, jaki występuje w przyrodzie. Nasze pytanie możemy również nazwać pytaniem o ontologiczny początek czasowy wszechświata z tego powodu, że chodzi przy nim - jak to podkreślał Teilhard ${ }^{12}$ - o początek metaempiryczny, początek nie dający się zarejestrować przyrodniczymi metodami badań, ani nawet pomyśleć z przyrodniczego punktu widzcnia. Trzeba jeszcze z dopiero co wymienionym autorem powiedziec więcej, że w przypadku istnienia tego początku, przyrodnik, który nigdy w ujęciu przedmiotów swego poznania nie zdoła się rozstać całkowicie z perspektywą czasową, mógłby bez k ońc a jakiekolwiek pojedyńcze zjawisko wiązać przyczynowo w charakterystycznym dla siebie rozumieniu ,fenomenologicznym” ${ }^{13}$ z innymi, poprzedzającymi je zjawiskami. Ten

10 Les fondements et le fond de l'idée d'évolution (esej z datą Wniebowstąpienia 1926 r.), Oeuvres, t. III: La vision du passé, Paris 1957, przypisy na s. 184 i 188.

11 Przy pomocy filozoficznej koncepcji czasu Stagiryty i Tomasza z Akwinu kosmolog - przyrodnik nie dokona żadnych konkretnych oszacowań liczbowych. Niemniej jednak ta koncepcja może stanowić wystarczającą podstawę do tego, by na gruncie filozofii przyrody mówić o fakcie lub przynajmniej o możliwości ontologicznego początku czasowego wszechświata. Tłumaczy się to tym, że filozof przyrody może brać pod uwagę kolejne stany kosmosu nie troszcząc się o problematykę empiriometrycznej strony czasu.

12 List do Augusta Valensin z 20 X 1919, fragment podany przez Emila Rideau w dziele La pensée du père Teilhard de Charin, Paris 1965, 381 (przyp. 25); Comment se pose aujourd'hui la question du transformisme, „Etudes", 162 (1921) Oeuvres, t. III, 39; Les fondements et le fond de l'idée d'évolution, tamże, 182-184, 188; Oeuvres, t. I: Le phénomène humain, Paris 1955, 43 (przyp.), 77-78; L'esprit nouveau, esej ukończony 13 lub 15 II 1942 r. - Oeuvres, t. V: L'avenir de l'homme, Paris 1959, 112-113; Agitation ou genèse? Position de l'homme et signification de la socialisation humaine dans la nature, szkic ukończony 20 XII 1947 r. — tamżc, 275.

13 Sens tego rozumienia ,fenomenologicznego" starałem się przedstawić w studium Próba rozwiąania problemu pochodzenia duszy ludzkiej, „Znak”, 13 (1961) $1188-1195$. 
stan rzeczy spróbuję wytłumaczyć inaczej, niż to robił Teilhard, który najczęściej powoływał się na to, co jest postulowane w naukowej teorii doświadczenia. Zacznę od ujęcia z zakresu filozofii przyrody, dla której wszechświat $\mathrm{z}$ początkiem ontologicznym nie daje się $\mathrm{w}$ żadnym swym stadium, nawet pierwszym, pojąć sensownie inaczej jak jako zamknięta w sobie całość coraz to nowych przyczyn i skutków, które kolejno się warunkują, nie posiadając $\mathrm{w}$ swych antecedensach jakiejś absolutnie pierwszej przyczyny z zakresu przyczyn wtórnych, jak powiedzielibyśmy ze stanowiska filozofii Boga po przeprowadzeniu argumentacji za Jego istnieniem. Transponując ten stan rzeczy na teren poznania przyrodniczego będziemy utrzymywali, że przyrodnik mógłby, z racji stałego występowania we wszechświecie zwartej w sobie jedności procesów, cofać się $\mathrm{w}$ nieskończoność przy właściwym sobie tłumaczeniu przyczynowym zjawisk.

Z tymi spostrzeżeniami oddaliliśmy się mocno od ujęcia takiego Pedro Descoqsa, który, polemizując ze stanowiskiem Teilharda, bronił racjonalnego charakteru tezy o absolutnym początku czasowym wszechświata w zakresie poszczególnych zjawisk ${ }^{14}$. Ta obrona dlatego nie może nas przekonać, gdyż Descoqs zakładał najwidoczniej coś nieprawdopodobnego, że mianowicie wszechświat, jakby jakaś gigantyczna taśma zjawisk, zwijał się kolejno zaczynając od absolutnie pierwszego zjawiska. Tymczasem gdy przyjmuje się, że wszechświat zawsze gdy był. stanowił kosmos, pewną powiązaną całość zjawisk, wówczas można utrzymywać, że, dla zamkniętego w sobie, przyczynowego „łańcucha” poszczególnych zjawisk, jest on nieograniczony w aspekcie czasowym, jak przyjąłem wyżej, natomiast gdy bierzemy go w całokształcie jego procesów, nie można wykluczyć tego, że pewne zjawiska były w nim absolutnie pierwsze, chociaż nie były takimi dla żadnych innych poszczególnych zjawisk. W przypadku zrealizowania się tej możliwości wszechświat byłby skończony w swym istnieniu. Posiadałby więc ontologiczny początek czasowy.

14 Autour de la crise du transformisme, Paris 1944, 85-91. 


\section{LE PROBLEME CONCERNANT \\ LE COMMENCEMENT TEMPORAIRE DE L'UNIVERS \\ EST-IL SENSE?}

\section{R E S U M E}

Le sens de la question concernant le commencement temporaire du cosmos semble être actuellement, chez certains auteurs, obscurci, soit par l'attribution du philosophique sens doctrinal à ce qui, dans la cosmologie contemporaine, constitue un symptôme d'un infinitisme ou bien du relativisme méthodologique, soit en conclusion d'une inadéquate interprétation, postulée de temps en temps, du concept relationnel de temps. Entre autres, c'est chez Michał Heller, un cosmologiste po. lonais, que nous trouvons des suggestions en direction de la solution doctrinale s'appuyant sur les fondements indiqués ci-dessus. L'étude présent constitue un essai de l'appréciation critique de ses opinions. 